\title{
Dynamics of Interleukin-10 Levels in Chronic Rhinosinusitis with/without Allergy
}

\author{
Abdul Qadar Punagi ${ }^{1, *}$, Sutji Pratiwi Rahardjo ${ }^{1}$ \\ ${ }^{1}$ Department of Ear, Nose and Throat, Faculty of Medicine, Hasanuddin University, Jl. Perintis Kemerdekaan Km.10, Makassar, Indonesia \\ ${ }^{*}$ Corresponding author. E-mail: qa_dar@yahoo.co.id
}

Received date: May 20, 2015; Revised date: Aug 24, 2015; Accepted date: Sep 2, 2015

\section{Abstract}

$\mathrm{B}$ ACKGROUND: Rhinosinusitis occurs when the lining of the nasal and sinuses gets inflamed, infected or irritated, become swollen, and create extra mucus, the swollen lining may also interfere with drainage of mucus. Chronic rhinosinusitis (CRS) is a more persistent problem that requires a specific treatment approach. Aim of this study was to determine changes in interleukin (IL)-10 as an anti-inflammatory cytokines in allergic and non-allergic CRS at Makassar.

METHODS: A prospective cohort study was designed to assess the level of IL-10 for three times during two weeks of therapy. Medication of Cefadroxil $500 \mathrm{mg} 2 \times 1$, Pseudoephedrine $30 \mathrm{mg} 2 \times 1$, Terfenadine $40 \mathrm{mg} \mathrm{2x1}$ and Methylprednisolone $4 \mathrm{mg} 3 \times 1$, was conducted during two weeks for 13 subjects in allergic CRS group and 12 subjects non-allergic CRS group. Results were statistically analyzed with student $\mathrm{t}$-test and paired $\mathrm{t}$-test.

RESULTS: The changes in levels of IL-10 in allergic CRS group were increased, but not significant (5.293 to 5.769, $\mathrm{p}=0.058)$, and in non-allergic CRS group were decreased, but not significant (6.125 to $5.475, \mathrm{p}=0.103$ ).

CONCLUSION: The serum levels of IL-10 were not significant increased in allergic CRS group and not significant decreased in non-allergic CRS group.

KEYWORDS: interleukin-10, chronic rhinosinusitis, allergy, Cefadroxil, Pseudoephedrine, Terfenadine, Methylprednisolone

Indones Biomed J. 2015; 7(3): 163-6

\section{Introduction}

Rhinosinusitis is an issue for general practitioners and Ear, Nose, and Throat (ENT) specialists due to its complex etiology, high prevalence and also its management which has not been coincident. Commonly, rhinogenic chronic rhinosinusitis (CRS) was developed because of untreated acute rhinosinusitis.(1) Rhinosinusitis influences about 35 million American people in a year and at least 16 million people admitted to hospital with related diagnosis according to National Ambulatory Medical Care Survey (NAMCS).
About $14 \%$ adult people suffering episodic rhinosinusitis every year and received antibiotic medication for the diagnosis. The incidence of rhinosinusitis in adult patients who came to outpatient clinic of Department of ENT, Dr. Cipto Mangunkusumo National Central General Hospital, during January to December 2005 was 435 patients (44.5\%). While in Makassar, 1092 visits (41.5\%) of rhinologic cases were reported in teaching hospitals, during 2003-2007.(2)

Rhinosinusitis, one of public medical issues, has became an economic burden on society. It may be caused by allergy, anatomical abnormality, polyp formation, and mucociliary dysfunction. Right diagnosis and proper 
treatment were obtained after a good anamnesis, and thorough physical assessment and work up.

Nasal obstruction and headache are the most common symptoms of CRS.(3) CRS could be caused by allergic and non allergic factors. Allergic CRS is caused by immunologically mediated inflammation, most often Immunoglobulin-E dependent, where as non allergic CRS is more likely caused by infection of gram negative bacterias and anaerobes. Rhinology study group of PERHATI-KL has recommended antibiotic combined with symptomatic therapy (such as decongestant, steroids, mucolytic, and nasal douching), therefore in this study we used Cefadroxil 500

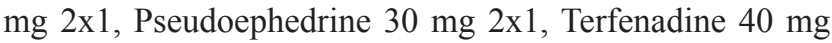
$2 \times 1$ and Methylprednisolone $4 \mathrm{mg} 3 \times 1$, as the protocol of CRS management.(4) Antihistamines and immunotherapy are given in severe allergic CRS.

Sharma, et al., has reported increase of infiltrated inflammatory cells and decrease of interference of regulatory $\mathrm{T}$ cells (T-reg).(5) However, there is no difference on T-reg in peripheral blood count which observed on subject whose CRS with nasal polyp (NP) and without NP. The lower level of interleukin (IL)-10 and transforming growth factor (TGF)-1 with higher level of pro-inflammatory cytokines (tumor necrosis factor (TNF) dan IL-6) were observed more in CRS than in control subjects. IL-10 was known as an anti-inflammatory cytokine, which could inhibit antigen presentation.

Study by Sobol, et al., showed different inflammatory cells and cytokine profiles between subjects with CRS and cystic fibrosis (CF).(6) Higher level of neutrophil, macrophage, and cells expressing mRNA for interferon $\gamma$ and IL-8 was found higher in CF subjects compared to CRS subjects or control group. Eosinophil and cells expressing mRNA for IL-4, IL-5, and IL-10 were higher in the CRS subjects compared to CF subjects and control.

\section{Methods}

A cohort study was performed involving 25 subjects from ENT outpatient clinic of Dr. Wahidin Sudirohusodo Hospital from July to October 2013. Subjects signed the informed consent prior to the study engagement. Ethical approval for this study was released by the Ethics Committee of Human Protection in Biomedical Research, Faculty of Medicine, Hasanuddin University, number 1036/H4.8.4.5.31/PP36KOMETIK/2013.

Skin Prick test was performed to divide the subjects into groups with and without allergy. We measured the level of IL-10 using Enzyme Linked Immuno Sorbent Assay (ELISA) method for plasma samples. Therapy was conducted based on Indonesian Rhinology Study Group and Indonesian ENT Specialist Association: Cefadroxil

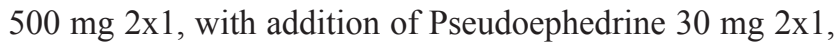
Terfenadine $40 \mathrm{mg} \mathrm{2 \times 1}$ and Methylprednisolon $4 \mathrm{mg} 3 \times 1$. Specimens were collected three times: before, during and post therapies. Student's t-test and paired t-test were used in the statistical analysis to compare two mean values with significance $p<0.05$.

\section{Results}

This study was performed on 25 CRS subjects, where as 13 subjects were in allergic and 12 subjects were in nonallergic groups. Table 1 showed the general distribution

Table 1. Distribution of the sample by gender, age, and chief complaints

\begin{tabular}{lcc}
\hline \multicolumn{1}{c}{ Aspects } & n & \% \\
\hline Gender & 17 & 68 \\
Women & 8 & 32 \\
Men & $\mathbf{2 5}$ & $\mathbf{1 0 0}$ \\
Total & & \\
\hline Age & 4 & 16 \\
$10-<20$ years & 9 & 36 \\
20 - <30 years & 8 & 32 \\
30 - <40 years & 3 & 12 \\
40 - <50 years & 1 & 4 \\
$\geq 50$ years & $\mathbf{2 5}$ & $\mathbf{1 0 0}$ \\
Total & & \\
\hline Chief complaints & & 36 \\
Rhinorrea & 9 & 20 \\
Nasal Obstruction & 5 & $\mathbf{1 0 0}$ \\
Cephalgia & 11 & 44 \\
\hline Total & $\mathbf{2 5}$ & \\
\hline & & \\
\hline
\end{tabular}


Table 2. IL-10 level of allergic CRS group during therapy.

\begin{tabular}{|c|c|c|c|c|c|}
\hline \multirow{2}{*}{ No. } & & \multirow{2}{*}{$\mathbf{n}$} & \multicolumn{3}{|c|}{ IL-10 } \\
\hline & & & Mean (pg/ml) & SD & $\mathbf{P}$ \\
\hline \multirow[t]{2}{*}{1} & Before therapy & 13 & 5.293 & 0.446 & 0.183 \\
\hline & After 1-week therapy & 13 & 5.731 & 1.172 & \\
\hline \multirow[t]{2}{*}{2} & After 1-week therapy & 13 & 5.731 & 1.172 & 0.907 \\
\hline & After 2-week therapy & 13 & 5.769 & 0.67 & \\
\hline \multirow[t]{2}{*}{3} & Before therapy & 13 & 5.293 & 0.446 & 0.058 \\
\hline & After 2-week therapy & 13 & 5.769 & 0.67 & \\
\hline
\end{tabular}

Table 3. IL-10 level of non-allergic CRS group during therapy.

\begin{tabular}{|c|c|c|c|c|c|}
\hline \multirow{2}{*}{ No. } & & \multirow{2}{*}{ n } & \multicolumn{3}{|c|}{ IL-10 } \\
\hline & & & Mean $(\mathrm{pg} / \mathrm{ml})$ & SD & $\mathbf{P}$ \\
\hline \multirow[t]{2}{*}{1} & Before therapy & 12 & 6.125 & 1.306 & 0.832 \\
\hline & After 1-week therapy & 12 & 6.117 & 1.699 & \\
\hline \multirow[t]{2}{*}{2} & After 1-week therapy & 12 & 6.117 & 1.699 & 0.088 \\
\hline & After 2-week therapy & 12 & 5.475 & 0.733 & \\
\hline \multirow[t]{2}{*}{3} & Before therapy & 12 & 6.125 & 1.306 & 0.103 \\
\hline & After 2-week therapy & 12 & 5.475 & 0.733 & \\
\hline
\end{tabular}

data of subjects population. Table 2 showed the changes of IL-10 concentrations in allergic group during two weeks of therapy. There were slight increases for IL-10 concentrations, but not significant. Table 3 showed the changes of IL-10 concentrations in non-allergic group during two weeks of therapy. There were slight increases for IL-10 concentration, but not significant.

\section{Discussion}

Our study involved $68 \%$ females and $32 \%$ males, or 2:1 in ratio. File and Rismayanti reported similar ratios, 1.7:1 and 1.3:1, respectively.(7,8) Most of our subjects aged from 20-39 years old. Rahmi, et al., suggested that CRS are commonly found in productive age, 24-29 years old (18.8\%).(3)

Our study showed a different phenomenon of IL-10 level after therapy, between allergic and non-allergic CRS groups. In allergic group, the IL-10 levels were increased, while in non-allergic group the IL-10 levels were decreased. IL-10 levels were found to be higher in non-allergic group. These results were in accordance to the results reported by Perić, et al., who also reported a higher level of IL-10 in patient with NP without asthma than NP with asthma.(9)

On the last day of two weeks therapy, levels of IL10 were higher in the allergic than non-allergic groups. The persistent allergen exposure may lead to the persistent inflammation, it could be the reason of this condition. Statistical analysis showed no significant differences for IL10 level of each group at nasal lavage specimen collection time (before, 1-week and 2-week post-therapies). However, changes in the level of IL-10 after 2-week therapy indicated a good response to therapy and showed an evidence-based protocol of 10 to 15 days therapy as recommended by Rhinology study group of PERHATI-KL.

Another study conducted by Savolainen, et al., showed a significant increase level of IL-10, after one year of pollen immunotherapy.(10) Bolard, et al., evaluated 


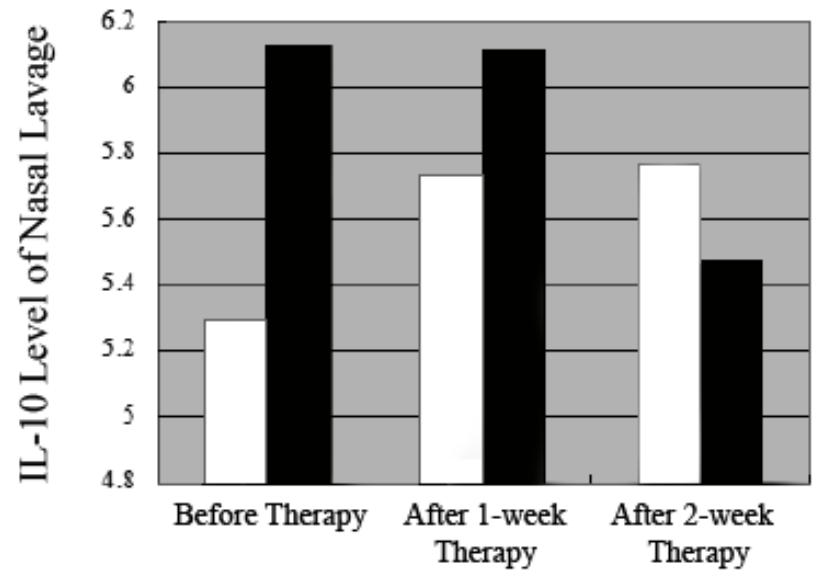

Figure 1. IL-10 level of allergic and non-allergic CRS groups differences during therapy. White bar: allegic CRS; Black bar: non-allergic CRS.

the characteristics (cells and mediators) of nasal lavages in 9 untreated NP patients (A group), 17 patients treated with topical steroids (B group), 21 patients treated with endonasal ethmoidectomy associated with topical steroids (C group), and 12 healthy subjects (control group).(11) IL8, IL-10, and IL-1 $\beta$ levels were significantly higher in C group than in A and B and control groups. TNF- $\alpha$ level was significantly lower in $\mathrm{C}$ group than in $\mathrm{A}$ and $\mathrm{B}$ and control groups; and there was a negative correlation between IL-10 and TNF- $\alpha$. In $\mathrm{C}$ group, asthmatic patients had a significant higher level of IL-10 than non-asthmatic patients. They concluded that topical steroid treatment was associated with a decrease of inflammatory cells and mediators. In marked contrast, nasal surgery was associated with marked changes, in cytokine profile in nasal secretions, that are clearly different from those of controls and topical steroid-treated NP patients, where as steroids up-regulated constitutive IL10 production.

As we mentioned earlier, the different mean level of IL-10 after 2-week therapy among the two groups might caused by persistent allergic exposure that may lead to the persistent inflammation. The possible pathologic overviews were an overlapping stimulation from infectious and noninfectious factors. Prolonged inflammation proposed the secondary infection.

\section{Conclusion}

The serum levels of IL 10 were not significant increased in allergic CRS group and not significant decreased in nonallergic rhinosinusitis CRS subjects.

\section{References}

1. Mulyarjo. Diagnosis Klinik Rinosinusitis. In: Mulyarjo, Soedjak S, Kentjono WA, Harmadji S, Herawati S, editors. Naskah Lengkap Perkembangan Terkini Diagnosis dan Penatalaksanaan Rinosinusitis. Surabaya: Bagian Ilmu Kesehatan THT FK Universitas Airlangga/RS Dr. Soetomo; 2004. p.17-24.

2. Benninger M, Gottschall J. Rhinosinusitis: Clinical Presentation and Diagnosis. In: Brook I, editor. Sinusitis from Microbiology to Management. New York: Taylor and Francis Group; 2006. p.39-52.

3. Rahmi AD, Punagi Q. Pola Penyakit sub Bagian Rinologi di RS Pendidikan Makassar periode 2003-2008. Makassar: Bagian Ilmu Kesehatan THT-KL FK Universitas Hasanuddin; 2008.

4. Mangunkusumo E, Soetjipto D. Sinusitis. In: Soepardi EA, Iskandar N, Bashiruddin J, Restuti RD, editors. Buku Ajar Ilmu Kesehatan Telinga Hidung Tenggorok Kepala dan Leher. 6th ed. Jakarta. Jakarta: Balai Penerbit FKUI; 2007 p.150-4.

5. Sharma S, Watanabe S, Sivam A, Wang J, Neuwirth SJ, Perez RI, et al. Peripheral blood and tissue $\mathrm{T}$ regulatory cells in chronic rhinosinusitis. Am J Rhinol Allergy. 2012; 26: 371-9.

6. Sobol SE, Christodoulopoulos P, Manoukian JJ, Hauber HP, Frenkiel $\mathrm{S}$, Desrosiers $\mathrm{M}$, et al. Cytokine profile of chronic sinusitis in patients with cystic fibrosis. Arch Otolaryngol Head Neck Surg. 2002; 128:1295-8.

7. File Jr TM. Sinusitis; Epidemiology. In: Brook I, editor. Sinusitis from Microbiology to Management. New York: Taylor and Francis Group; 2006. p.2-5.

8. Rismayanti. Pengaruh Rinosinusitis Kronis terhadap gangguan fungsi ventilasi tuba Eustachius (Thesis). Makassar: Universitas Hasanuddin; 2009.

9. Perić A, Vojvodić D, Radulović V, Vukomanović-Durdević B, Perić $\mathrm{AV}$, Miljanović O. Proinflammatory cytokine levels in nasal fluid as indicators of severity of nasal polyposis. Acta Clin Croat. 2010; 49: 395-403.

10. Savolainen J, Laaksonen K, Rantio-Lehtimäki A, Terho EO. Increased expression of allergen-induced in vitro interleukin-10 and interleukin-18 mRNA in peripheral blood mononuclear cells of allergic rhinitis patients after specific immunotherapy. Clin Exp Allergy. 2004; 4: 413-9.

11. Bolard F, Gosset P, Lamblin C, Bergoin C, Tonnel AB, Wallaert B. Cell and cytokine profiles in nasal secretions from patients with nasal polyposis : effects of topical steroids and surgical treatment. Allergy. 2001; 56: 333-8. 